\title{
ДОСВІД ПІДВИЩЕННЯ КВАЛІФІКАЦІЇ ВИКЛАДАЧІВ ВИЩОЇ ШКОЛИ У ВЕЛИКІЙ БРИТАНІЇ
}

\author{
Старостіна O. B. \\ кандидат педагогічних наук, \\ дочент кафедри іноземних мов професійного спілкування \\ Міжнародний гуманітарний університет \\ вул. Фонтанська дорога, 33, Одеса, Украӥна \\ orcid.org/0000-0002-4546-8745 \\ stat0707@ukr.net
}

\begin{abstract}
Ключові слова:
підвищення кваліфікації, професійне зростання, вища школа, університет, науковопедагогічні кадри, мережевий підхід, Великобританія.
\end{abstract}

У статті розглянуто досвід підвищення кваліфікації викладачів вищої школи у Великій Британії. Зазначено, що позитивний досвід системи навчання викладачів вищої школи Великобританії, який грунтується на сучасних концептуальних положеннях та технологічних моделях, має беззаперечну цінність для вивчення та імплементації у вітчизняну систему освіти. Констатовано, що процес підвищення кваліфікації науково-педагогічних кадрів в університетах цієї країни здійснюється за допомогою різних структурних підрозділів, що створюються самими закладами вищої освіти. Встановлено, що в основу організації підвищення кваліфікації педагогів Великої Британії закладені ідеї мережевого підходу. Зазначено, що підвищення кваліфікації у вищих навчальних закладах країни здійснюється індивідуально та адресно і має практико-орієнтований характер. Із цією метою активно застосовуються мультимедійні, електронні та дистанційні засоби і різноманітні форми від консультацій, практикумів до дискусійних панелей, онлайн-семінарів та варіативних методів, таких як «навчання дією», «менторство», «коучинг», «наставництво», «піраміда», «акваріум» тощо. Загалом Великобританія спирається на індивідуалізовані форми підвищення кваліфікації, які визначаються вибором самого викладача. При цьому тут немає законодавчо встановлених вимог щодо навчання на курсах професійного розвитку викладачів вищої школи; їх постійне професійне зростання - це відповідальність кожного університету, більшість 3 яких має власні відділи або працівників, відповідальних за професійний розвиток персоналу. Також більшість розробників курсів підвищення кваліфікації використовують так зване віртуальне навчальне середовище університетів, яке з'явилося внаслідок розвитку нових інформаційних технологій та змінило систему освіти країни загалом. Воно дає змогу працювати онлайн із великими і малими групами слухачів, а також проводити заняття індивідуально. Розвиток електронного навчання в сучасних закладах вищої освіти Великобританії сприяв тому, що процес підвищення кваліфікації викладачів вишів став більш гнучким, відкритим і персональним. Розглянуті в статті методи і форми, використовувані на курсах підвищення кваліфікації в університетах Сполученого Королівства, уможливили висновок про те, що вони сприяють не тільки професійному зростанню науково-педагогічних кадрів вищих навчальних закладів країни, а й надають їм психологічну підтримку, мотивують на вирішення складних питань і подолання труднощів у роботі. 
TRAINING EXPERIENCE FOR HIGHER SCHOOL TEACHERS IN THE UK

\author{
Starostina O. V. \\ Candidate of Pedagogical Sciences, \\ Associate Professor at the Department of Foreign Languages for Professional Communication \\ International Humanitarian University \\ Fontanska Doroha str., 33, Odesa, Ukraine \\ orcid.org/0000-0002-4546-8745 \\ stat0707@ukr.net
}

Key words:

professional development, professional growth, higher school, university, scientific and pedagogical staff, network approach, Great Britain.

\begin{abstract}
The article considers the experience of advanced training of higher education teachers in Great Britain. It is noted that the positive experience of the teaching system of higher education teachers in Great Britain, based on modern conceptual provisions and technological models, is of undeniable value for study and implementation in the domestic education system. It is stated that the process of professional development of scientific and pedagogical staff in the universities of this country is carried out with the help of various structural units created by the universities themselves. It is established that the ideas of the network approach are the basis of the organization of professional development of teachers of Great Britain. It is noted that advanced training in higher educational institutions of the country is carried out individually and in a targeted manner and has a practice-oriented nature. At the same time, multimedia, electronic and remote means are actively used various forms - from consultations, workshops in discussion panels, online seminars and variable methods such as "learning by doing", "mentoring", "coaching", "mentoring", "pyramid", "aquarium" and others. In general, the United Kingdom relies on individualized forms of professional development, determined by the choice of the teacher. At the same time, there are no legally established requirements for training in professional development courses for higher school teachers; their constant professional growth is the responsibility of each university, most of which have their own departments or employees responsible for the professional development of personnel. Also, most developers of advanced training courses use the so-called virtual training center of universities, which appeared as a result of the development of new information technologies and changed the country's education system as a whole. It allows you to work online with large and small groups of students, as well as to conduct classes individually. The development of e-learning in modern UK universities has contributed to the fact that the process of professional development of university teachers has become more flexible, open and personal. The methods and forms used in the article, used in refresher courses at universities in the United Kingdom, concluded that they not only contribute to the professional growth of scientific and pedagogical staff of higher education institutions in the country, but also provide them with psychological support, motivate them to solve complex problems and overcoming difficulties in work.
\end{abstract}

Постановка проблеми. В Україні триває реформа вищої школи. Її реалізація пов'язана 3 вивченням та пошуком варіантів впровадження найкращих світових практик. Значний інтерес у цьому сенсі становить система вищої освіти Великобританії як батьківщини багаторічного досвіду, сучасних освітніх стратегій і технологій підготовки фахівців найвищої кваліфікації, зокрема викладацьких кадрів для закладів вищої освіти.
Позитивний досвід системи навчання викладачів вищої школи Великобританії, який грунтується на сучасних концептуальних положеннях та технологічних моделях, має беззаперечну цінність для вивчення та імплементації у вітчизняну систему освіти. Тому цей досвід потребує окремого наукового дослідження та узагальнення.

Аналіз останніх досліджень і публікацій. Питання підвищення кваліфікації вчителів у 
системі освіти Великої Британії досліджували В.I. Гарапко [1], М.В. Кривоніс [2], А.П. Чичук [3]. Проте стосовно викладачів вищої школи Великобританії цьому аспекту не приділено достатньої уваги в наявних наукових дослідженнях.

Метою статті $\epsilon$ вивчення досвіду підвищення кваліфікації викладачів вищої школи у Великобританії.

Виклад основного матеріалу. Для підвищення кваліфікації викладачів вищої школи Великобританії є спеціальні програми і курси, після закінчення яких видається післядипломний сертифікат. Завдяки ним завжди є змога розширити свої знання як за власною, так і за суміжними дисциплінами. Сертифікат акредитується Академією вищої освіти.

Удосконалення кваліфікації викладачів вищої школи Великобританії в професійному плані здійснюється також у неформальних умовах, у рамках соціальної взаємодії педагогів. Неформальна обстановка дає змогу зняти психологічний бар'єр у процесі взаємодії викладачів, більш ефективно здійснити обмін знаннями та досвідом, виявити загальні інтереси, обговорити професійні питання дискусійного характеру, запропонувати варіанти подальшої взаємодії. Неформальні умови, в яких також відбувається вдосконалення професійної майстерності педагогів, нерідко доповнюють розроблені офіційні курси підвищення кваліфікації науково-педагогічних кадрів. Завдяки ним створюються ширші можливості для вдосконалення педагогічної практики, аніж при традиційних акредитованих програмах підвищення кваліфікації.

Вивчаючи вплив діяльності кафедр університетів на професійне зростання академічного персоналу закладів вищої освіти, дослідники у своїх роботах аналізують ефективність централізованих навчальних програм підвищення кваліфікації, що традиційно домінують. На думку А. Брю, академічні кафедри варто розглядати як «спільноти практикуючих» [4, с. 112]. Своєю чергою Е. Венгер підкреслює необхідність взаємодії «спільнот практикуючих», оскільки це сприяе якісній зміні процесів підвищення кваліфікації у вищій школі [5, с. 247].

Водночас основну функцію розвитку вищих освітніх установ Великобританії та підвищення кваліфікації їх науково-педагогічних кадрів покладено на заклади вищої освіти. Відповідальність за просування передових ідей у сфері освіти традиційно покладається на відділи освітнього розвитку [6]. Роль відділів освітнього розвитку в британських вишах полягає в забезпеченні підвищення кваліфікації науково-педагогічних кадрів, ïх відповідальності за реалізацію стратегій у навчальному процесі та викладанні, заохоченні інновацій та поліпшенні якості навчання.
Близько половини сучасних відділів освітнього розвитку розташовуються в кадрових службах, бібліотечних або інформаційних відділах університетів, 40\% 3 них є автономними одиницями, $10 \%$ працюють у рамках певного факультету. Очільник відділу зазвичай підпорядковується заступнику ректора університету, що займається управлінням, дослідницькою та науковою діяльністю, або ж віце-канцлеру, що відповідає за навчальну роботу.

Відділи освітнього розвитку мають стратегічно важливе значення для установи вищої освіти, бо відповідають за розробку й реалізацію (часто у співпраці з іншими підрозділами) широкого спектра стратегій, у тому числі «Стратегії навчання» [7]. При цьому вони відповідальні ще й за організацію електронного навчання. Підтримка педагогічної науки та зміцнення зв'язку між викладанням i науковими дослідженнями нині є пріоритетною метою британських відділів освітнього розвитку. Майже 3/4 цих відділів серед своїх функцій мають обов'язок сприяння педагогічним дослідженням. Більшість таких відділів відповідають за проведення акредитованих курсів підвищення професійної кваліфікації для викладачів-початківців.

Відділи освітнього розвитку, організовуючи підвищення кваліфікації науково-педагогічних кадрів, активно використовують у своїй практиці ідеї мережевого підходу. Так, донедавна вони активно взаємодіяли 3 Центрами передового досвіду в галузі навчання, створеними 3 метою фінансування, заохочення і подальшого розвитку навчання на високому рівні в британській вищій школі, а також із предметними центрами, організованими для надання професійної допомоги науково-педагогічним кадрам різних вишів у галузі викладання конкретної дисципліни. Нині діяльність низки Центрів передового досвіду в галузі навчання припинено, а функціональні обов'язки предметних центрів передані Академії вищої освіти. Однак це не означає, що робота із забезпечення взаємодії відділів освітнього розвитку з іншими структурами припинена. Відбувається пошук нових варіантів взаємодії з фахівцями різних напрямів, актуальних для того чи іншого закладу вищої освіти в плані підвищення кваліфікації науково-педагогічних кадрів вищої школи з урахуванням специфіки їх корпоративної політики.

Сучасні відділи освітнього розвитку продовжують реструктурувати і реорганізовувати. Реструктуризація зазвичай пов'язана з об'єднанням або розподілом їх функцій, таких як забезпечення електронного навчання, підвищення кваліфікації науково-педагогічних кадрів, вдосконалення якості викладання. Реорганізація часто пов'язана 
зі зміною керівництва, відповідального за діяльність відділів освітнього розвитку. Відповідно до перетворень змінюються функції, виконувані працівниками цих відділів. Вони пов'язані з контролем якості навчання та його вдосконаленням, зі здійсненням педагогічних досліджень, забезпеченням електронного навчання, підготовкою аспірантів тощо.

Загалом у Великобританії немає законодавчо встановлених вимог щодо навчання на курсах професійного розвитку викладачів вищої школи; ïх постійне професійне зростання - це відповідальність кожного університету, більшість 3 яких має свої власні відділи або працівників, відповідальних за професійний розвиток персоналу. Ними розробляються програми навчання як для своїх викладачів, так і для колег з інших вишів. Акредитація та фінансування деяких програм навчання в секторі вищої освіти здійснюється Академією вищої освіти Великої Британії, Асоціацією розвитку освіти і персоналу за підтримки Фонду лідерства вищої освіти, який вивчає інноваційні процеси в національних освітніх системах. Вони також розробляють програми постійного вдосконалення професійної підготовки науково-педагогічних кадрів вищої школи за активної участі вищих навчальних закладів і професійних асоціацій, що базуються на сучасних наукових відкриттях та інноваційних педагогічних технологіях.

У Великій Британії також є центри дидактики вищої школи. Вони проводять не тільки групові заняття, а й індивідуальні, на яких можна отримати консультації з багатьох питань, а також організовують різноманітні курси та семінари. Такі курси і семінари служать форумом для колег, де обговорюються нові педагогічні технології та де вони отримують знання за програмами, що дає більш фундаментальну підготовку для практичної діяльності, дослідницької та наукової роботи.

Крім того, в британських вишах велике значення надається розробці авторських курсів і програм, тому що читання лекції «за підручником» вважається принизливим для викладача і факультету. Спираючись на новітні наукові досягнення, викладачі щорічно удосконалюють свої програми.

Загалом Великобританія спирається на індивідуалізовані форми підвищення кваліфікації, які визначаються вибором самого викладача. Тут доволі суворо витримується обов'язок постійної дослідницької роботи всіх університетських викладачів, але за такою роботою не «спускається» план та не дається «розкладка» тем. Надається академічна відпустка, коли викладач йде на річну «польову роботу» або наукове стажування (але він не може використовувати цей час, відпочиваючи або забезпечуючи собі додатковий заробіток). Працює система «зовнішніх екзамена- торів», коли викладачі різних університетів перехресно оцінюють роботу один одного, взаємно переймаючи професійний досвід. Останнім часом активно діє система «горизонтальної» взаємооцінки всередині та між факультетами, яка сприяє передачі й поширенню викладацького та дослідницького досвіду.

Загалом викладач британського університету знаходиться під своєрідним неформальним, але постійним тиском професійного середовища, що спонукає до подальшого підвищення кваліфікації. Крім того, відбувається щорічна оцінка його роботи, яка спирається як на формалізовану письмову самооцінку в рамках академічного огляду, так і на взаємну оцінку колег. До того ж університети регулярно проводить анкетування студентів із метою виявлення оцінки навчального процесу, рейтингу викладачів, виявлення слабких і сильних сторін діяльності факультетів університету. Під час здійснення такого анкетування суворо дотримується принцип конфіденційності. Результати опитування надають важливу інформацію для аналізу роботи викладачів та пошуку шляхів iї вдосконалення.

Кожен британський заклад вищої освіти розробляє стратегію підвищення кваліфікації свого персоналу на основі довгострокового навчального плану. Така діяльність $\epsilon$ центральним напрямом розвитку вишів і може включати формальне навчання педагогічних кадрів, отримання ними другої освіти, вивчення досвіду колег та інші види діяльності, що ведуть до змін навичок та умінь, які потім будуть використані викладачами на практиці. Підвищення кваліфікації персоналу закладів вищої освіти передбачає також навчання вміння самостійно знаходити рішення поставлених завдань і ефективного застосування сучасних технологій у професійній діяльності.

Високий рівень наукових досліджень і підготовки наукових кадрів у закладах вищої освіти Великобританії досягається істотно завдяки тому, що наставниками більш молодих дослідників $€$ всебічно підготовлені наукові співробітники, що належать до інтелектуальної еліти Сполученого Королівства.

Поряд із розглянутими формами підвищення кваліфікації науково-педагогічних кадрів вищих навчальних закладів у Великобританії $є$ інші альтернативні форми. Такими формами $є$ академічна відпустка, наукові стажування, оцінка колег, консультування з більш досвідченими науково-педагогічними кадрами тощо.

Для адаптації викладачів-початківців до умов їх майбутньої роботи адміністрацією університетів надається широкий ряд можливостей для ознайомлення 3 особливостями організації та освітньої політики вишу. Тому «менторинг» або 
«наставництво» $є$ необхідною умовою «введення у професію» такого викладача на його робочому місці [8, с. 619]. Надалі їм як «викладачам зі стажем» пропонуються варіативні курси підвищення кваліфікації, які вони можуть відвідувати в зручний час або дистанційно.

Більш досвідчені викладачі призначаються «менторами» для більш молодих. При цьому «старший» колега несе відповідальність і за забезпечення комфортної психологічної обстановки навколо кожного викладача. 3 цього випливає, що в більш досвідчених академічних кадрів мають бути певні знання в галузі педагогіки і психології, які вони можуть постійно вдосконалювати, відвідуючи численні курси підвищення кваліфікації у виші. Крім того, міжнародні відрядження і співробітництво, участь у науково-практичних конференціях також сприяють їх безперервному професійному розвитку.

Є різні види наставництва: індивідуальне та групове (за кількістю учасників у цьому процесі), щодо початківців і досвідчених колег (з огляду на досвід професійної роботи). Метод наставництва часто використовується неофіційно. Наприклад, у ситуаціях необхідної професійної допомоги або підтримки з боку колег.

Метод наставництва спирається на такі життєві цінності та принципи [9, с. 160]: визнання можливості особистісного росту людини; розуміння того, як люди вчаться; визнання індивідуальних особливостей людини; розширення можливостей iї особистісного і професійного зростання; розвиток всіх видів компетенцій; пошук нових ідей, теорій і знань; вивчення минулого досвіду людини; погляд у майбутне і розвиток здібностей до передачі знань та їх застосування в нових ситуаціях тощо.

Можна виділити дві моделі наставництва. Перша модель заснована на спільній взаємодії викладачів, більш рівних за статусом в академічному середовищі. Інший, більш традиційний підхід, заснований на моделі розвитку, де більш досвідчений працівник консультує i спрямовує діяльність менш досвідченого. При цьому стаж і досвід роботи ментора $є$ визначальними факторами. Наставник розглядається як радник, «адвокат», «зразок для наслідування». На нього покладається відповідальність за підготовку нового співробітника вишу відповідно до його інституційної політики. Обов'язки ментора змінюються залежно від конкретних ситуацій і потреб людей, залучених у цей процес.

Також доцільно зазначити інші найбільш популярні методи, що використовуються відділами (центрами) та іншими структурними підрозділами на курсах підвищення кваліфікації в різних вишах Сполученого Королівства. Наприклад, «навчання дією» - сучасний освітній метод, який передбачає вивчення слухачами власних дій і досвіду для того, щоб удосконалити якість своєї роботи. Учасник курсу або семінарського заняття набуває знання, виходячи з фактичних дій і практики, а не за допомогою традиційних методик. Цей метод дає змогу кожній людині осмислити та критично проаналізувати ті рішення, які були прийняті нею в тих чи інших ситуаціях.

Популярна нині методика «змішаного навчання» застосовується на курсах підвищення кваліфікації у Великобританії досить тривалий час. Змішане навчання являс собою поєднання традиційних (аудиторних) та електронного методів навчання. При цьому активно використовуються засоби масової інформації, соціальні мережі та мікроблоги. Як показує практика, результати навчання на курсах із застосуванням цього методу стали кращими [10, с. 141].

Нині у Великобританії метод «спостереження за роботою колег» $є$ одним із найпоширеніших способів безпосередньо отримати уявлення про роботу викладача закладу вищої освіти за невеликий проміжок часу. Цей метод має на увазі спостереження молодого фахівця за діяльністю більш досвідченого колеги щодня для того, щоб усвідомити, якими правами і обов'язками володіє академічний персонал вишу. Слухачі мають бути максимально зосереджені на тому, що відбувається. Крім того, цей метод передбачає застосування рефлексивної діяльності, оскільки кожен молодий спеціаліст має зрештою протягом однієї-двох годин описати всі ті нові для себе функції, з якими він зіткнувся в процесі спостереження за роботою свого колеги за цілий день. Таким чином, метод «спостереження за роботою колег» дає змогу безпосередньо побачити, що відбувається на кафедрі або факультеті та якою $є$ робоча обстановка. Він застосовується для вдосконалення власної педагогічної діяльності та є досить ефективним засобом підвищення кваліфікації викладача.

Метод «коучинг» також $є$ способом професійної підготовки та підвищення кваліфікації науково-педагогічних кадрів у Великій Британії. $€$ два типи коучингу: Skills Coaching i Transformational Coaching. Skills Coaching є взаємодією педагога-учня 3 педагогом-наставником (тренером) «один на один», із метою розвитку і вдосконалення професійних компетенцій. Transformational Coaching передбачає надання допомоги педагогом-наставником (тренером) у вирішенні нових або складних проблем в різних ситуаціях. Таким чином, «коучинг»є персоналізованим досвідом для співробітників університету, який сприяє розширенню їхніх знань, підвищенню рівня продуктивності праці та покращенню досвіду. $Є$ велика різноманітність моделей і форм реалізації цього 
методу. Деякі університети Великобританії в рамках підвищення кваліфікації педагогів використовують форму спілкування, за якої консультанти індивідуально або у групі (online, по телефону або особисто) задають питання і пропонують вибір можливих відповідей [11, с. 55-56].

На курсах підвищення кваліфікації науково-педагогічних кадрів використовують також i низку інших методів - метод дискусійних груп, метод «піраміди», метод «акваріум» тощо. Педагоги виконують практичні завдання, відпрацьовуючи прийоми реалізації цих методів в освітньому процесі. Так, метод дискусійних груп передбачає формування експромтом невеликих груп викладачів вищої школи, що складаються 3 двох або трьох учасників, які обговорюють те чи інше питання протягом короткого періоду часу. Це дає змогу бути більш активним у процесі навчання та формувати комунікаційні навички, що сприяють ефективній роботі з великими групами. Дискусійні групи сприяють активній участі кожного викладача в обговоренні тієї чи іншої теми. При цьому сам процес $є$ більш енергійним порівняно 3 виступом однієї людини перед групою людей. Цим процесом можна керувати, наприклад, визначати чіткі часові межі, застосовувати цей метод, якщо виникає пауза або проблемна ситуація на заняттях. Чим важчим є завдання, що стоїть перед слухачами, тим важливішим $є$ число учасників. Вважається, що більш продуктивно працюють групи, які складаються з трьох людей, у той час як робота в парі виявляється менш результативною.

Метод «піраміди» також відомий під назвою «снігова куля». Він полягає в залученні слухачів до роботи на заняттях індивідуально, потім у парах, у четвірці або шістці учасників i, зрештою, 3 усією групою. Працюючи індивідуально, слухач може познайомитися 3 деякими матеріалами самостійно, перш ніж його поставлять у пару 3 колегою. У парах учасники більш детально вивчають те чи інше питання, формують власну думку. У четвірках або шістках слухачі можуть висловлювати свою думку більш активно, оскільки вони вже робили це в парах. Спільна робота може приймати форму відкритого обговорення ідей, висунутих кожним із четвірки або шістки учасників. Таким чином, відбувається обмін думками вже на більш високому рівні. Часовий проміжок між стадіями залежить від розміру групи, але, як правило, складається 35 хвилин індивідуальної роботи, 15 хвилин обміну думками та обговорення в парах, 30 хвилин порівняння та обговорення ідей у четвірках або шістках, 10 хвилин спільної роботи. Цей метод дає змогу слухачам переходити від конкретного до абстрактного і від простого до складного. Роль викладача при цьому полягає в розробці інструкцій для кожного етапу, підказках слухачам, що робити далі та як організувати спільну роботу.

Метод «акваріум»- це спосіб обговорення проблеми у групі, учасниками якої стають всі ії представники. Одні добровільно йдуть в «акваріум» і активно обговорюють проблему, і тому сидять на стільцях, розташованих у внутрішньому колі (ï може бути від 5-7 до 10 осіб). Інші спостерігають за активними учасниками обговорення проблем у зовнішньому колі. Цей метод особливо ефективний у групах чисельністю понад 30 учасників. Ті 3 них, які перебувають у зовнішньому колі, можуть взяти участь в обговоренні, просто «видаливши» інших, хто перебуває в «акваріумі». Учасник із зовнішнього кола може замінити будь-якого в «акваріумі». Таким чином, в обговоренні проблеми можуть брати участь практично всі члени групи, періодично міняючись один 3 одним місцями (ролями).

Також варто зазначити, що у вишах Сполученого Королівства забезпечується підтримка в застосуванні різних електронних засобів навчання, більшість розробників курсів підвищення кваліфікації нині використовують так зване віртуальне навчальне середовище університетів. Ця форма організації навчального процесу з'явилася внаслідок розвитку нових інформаційних технологій та змінила систему освіти країни загалом. Віртуальне навчальне середовище університету дає змогу працювати online 3 великими і малими групами слухачів, а також проводити заняття індивідуально. Розвиток електронного навчання в сучасних вишах Великобританії суттєво сприяв тому, що процес підвищення кваліфікації викладачів закладів вищої освіти став більш гнучким, відкритим і персональним. Електронне навчання передбачає активне використання мультимедіа для забезпечення вдосконалення професійної діяльності науково-педагогічних кадрів вищих навчальних закладів. Необхідна інформація передається за допомогою мережі Інтернет, електронних носіїв інформації, супутникового телебачення і т. д. [12, с. 41].

Висновки. Таким чином, процес підвищення кваліфікації науково-педагогічних кадрів в університетах Великобританії здійснюється за допомогою різних структурних підрозділів, що створюються самими закладами вищої освіти (центрами, відділами, службами, управліннями).

В основу організації підвищення кваліфікації педагогів Великої Британії закладені ідеї мережевого підходу, що реалізується шляхом встановлення партнерських взаємовідносин викладачів та покращення їх комунікації з фахівцями структурних підрозділів ВН3, що позитивно впливає на рівень їхніх професійно-педагогічних здібностей. Також це реалізується шляхом покращення взаємодії викладачів різних вищих навчальних 
закладів та поліпшення комунікації 3 досвідченими фахівцями інших організацій, представниками бізнесу та різних секторів економіки і на цій основі активізації обміну досвідом і найкращими практиками.

Підвищення кваліфікації у вищих навчальних закладах Великої Британії здійснюється індивідуально та адресно і має практико орієнтований характер. Для цього використовуються різноманітні форми - від консультацій, практикумів до дискусійних панелей, онлайн-семінарів та варіативних методів, таких як «навчання дією», «менторство», «коучинг», «наставництво», «піраміда», «акваріум» тощо. При цьому активно застосовуються мультимедійні, електронні та дистанційні засоби.

Розглянуті методи, використовувані на курсах підвищення кваліфікації в університетах Сполу- ченого Королівства, дають змогу зробити висновок про те, що вони розвивають творче мислення слухачів курсів, мають практичну спрямованість, дають змогу колегам активно взаємодіяти і сприяють не тільки професійному зростанню науково-педагогічних кадрів вищих навчальних закладів Великобританії, а й надають їм психологічну підтримку, мотивують на вирішення складних питань і подолання труднощів у роботі.

Загалом результати підвищення кваліфікації науково-педагогічних кадрів вищих навчальних закладів Великобританії є досить високими.

Ця стаття не вичерпує усіх аспектів розглядуваної проблеми. Перспективами подальших досліджень у цьому напрямі є вивчення досвіду підвищення кваліфікації викладачів вищої школи в Україні та можливість імплементації досвіду Великої Британії у вітчизняну практику.

\section{Література}

1. Гарапко В.І. Сучасні урядові ініціативи щодо професійної освіти та підвищення кваліфікації вчителів у системі освіти Великої Британії. Професійна освіта: проблеми і перспективи. 2015. Вип. 8. C. $127-131$.

2. Кривоніс М.В. Підвищення кваліфікації вчителів Великої Британії як чинник високого професійного педагогічного рівня в країні. Вісник Житомирського державного університету імені Івана Франка. 2012. Вип. 63. С. 192-195.

3. Чичук А. Сучасні моделі навчання на курсах підвищення кваліфікації вчителів у Великій Британії. Рідна школа. 2016. № 7. С. 74-77.

4. Brew A. Teaching and Research: New relationships and their implications for inquiry-based teaching and learning in higher education. Higher Education Research \& Development. 2012. № 31. P. 101-114.

5. Wenger E. Communities of Practice: Learning, Meaning, and Identity. Cambridge University Press. 1999. $318 \mathrm{p}$.

6. Jones J., Wisker G. Educational Development in the United Kingdom: Report for the Heads of Educational Development Group (HEDG). Centre for Learning and Teaching University of Brighton. 2012. URL: http://www.hedg.ac.uk/ico/wp-ontent/uploads/2016/02/HEDGFinalReport2012.pdf (дата звернення: 10.08.2020).

7. Wieneke J., Spruce G. Tales of change: effective professional development in the light of educational systems reforms in Austria and England. Arts Education Policy Review. 2020. URL: https://doi.org/10.10 80/10632913.2020.1768188 (дата звернення: 10.08.2020).

8. Ambler T., Harvey M., Cahir J. University academics' experiences of learning through mentoring. Aust. Educ. Res. 2016. Vol. 43. Pp. 609-627.

9. Shanks R. Mentoring beginning teachers: professional learning for mentees and mentors. International Journal of Mentoring and Coaching in Education. 2017. Vol. 6. No. 3. P. 158-163.

10. Czerniawski G., Gray D., MacPhail A., Bain Y. The professional learning needs and priorities of highereducation-based teacher educators in England, Ireland and Scotland, Journal of Education for Teaching. Journal of Education for Teaching International research and pedagogy. 2018. Vol. 44. Iss. 2. P. $133-148$.

11. Lane L., Wilde J. The impact of coaching doctoral students at a university in London. Janet International Journal of Evidence Based Coaching and Mentoring. 2018. Vol. 16. No. 2. P. 55-68.

12. Liebowitz J., Frank M. Knowledge Management and E-Learning. CRC Press. 2016. 367 p.

\section{References}

1. Garapko V.I. (2015). Suchasni uriadovi initsiatyvy shchodo profesiinoi osvity ta pidvyshchennia kvalifikatsii vchyteliv u systemi osvity Velykoi Brytanii [Modern government initiatives for professional education and training of teachers in the education system of Great Britain]. Profesijna osvita: problemy $i$ perspektyvy [Professional education: problems and prospects]. 8, 127-131 (in Ukrainian).

2. Kryvonis M.V. (2012). Pidvyshchennia kvalifikatsii vchyteliv Velykoi Brytanii yak chynnyk vysokoho profesiinoho pedahohichnoho rivnia $\mathrm{v}$ kraini [Professional development of teachers in Great Britain as a 
factor of high professional pedagogical level in the country]. Visnyk Zhytomyrskoho derzhavnoho universytetu imeni Ivana Franka [Bulletin of Zhytomyr State University named after Ivan Franko]. 63, 192-195 (in Ukrainian).

3. Chychuk A. (2016). Suchasni modeli navchannia na kursakh pidvyshchennia kvalifikatsii vchyteliv u Velykii Brytanii [Current models of the courses and teacher training in the UK]. Ridna shkola [Native school]. 7, 74-77 (in Ukrainian).

4. Brew A. (2012). Teaching and Research: New relationships and their implications for inquiry-based teaching and learning in higher education. Higher Education Research \& Development, 31, 101-114 (in English).

5. Wenger E. (1999). Communities of Practice: Learning, Meaning, and Identity. Cambridge University Press, 318 (in English).

6. Jones J.\&. Wisker G. (2012). Educational Development in the United Kingdom: Report for the Heads of Educational Development Group (HEDG). Centre for Learning and Teaching University of Brighton. URL: http://www.hedg.ac.uk/ico/wp-ontent/uploads/2016/02/HEDGFinalReport2012.pdf (accessed 10 August 2020) (in English).

7. Wieneke J. \& Spruce G. (2020). Tales of change: effective professional development in the light of educational systems reforms in Austria and England. Arts Education Policy Review. URL: https://doi.org/10.10 80/10632913.2020.1768188 (accessed 10 August 2020) (in English).

8. Ambler T.\& Harvey M. (2016). University academics' experiences of learning through mentoring. Aust. Educ. Res, 43, 609-627 (in English).

9. Shanks R. (2017). Mentoring beginning teachers: professional learning for mentees and mentors. International Journal of Mentoring and Coaching in Education, 6, No. 3, 158-163(in English).

10. Czerniawski G.\& Gray D. (2018). The professional learning needs and priorities of higher-education-based teacher educators in England, Ireland and Scotland, Journal of Education for Teaching. Journal of Education for Teaching International research and pedagogy,44. Iss. 2, 133-148 (in English).

11. Lane L. \& Wilde J. (2018). The impact of coaching doctoral students at a university in London. Janet International Journal of Evidence Based Coaching and Mentoring, 16, No. 2, 55-68 (in English).

12. Liebowitz J.\& Frank M. (2016). Knowledge Management and E-Learning. CRC Press, 367 (in English). 